University of Nebraska - Lincoln

DigitalCommons@University of Nebraska - Lincoln

Faculty Publications from the Harold W. Manter Laboratory of Parasitology

1989

Coccidian Parasites (Apicomplexa: Eimeriidae) from Insectivores.

VIII. Four New Species from the Star-Nosed Mole, Condylura

cristata

Donald W. Duszynski

University of New Mexico, eimeria@unm.edu

Follow this and additional works at: https://digitalcommons.unl.edu/parasitologyfacpubs

Part of the Parasitology Commons

Duszynski, Donald W., "Coccidian Parasites (Apicomplexa: Eimeriidae) from Insectivores. VIII. Four New Species from the Star-Nosed Mole, Condylura cristata" (1989). Faculty Publications from the Harold W. Manter Laboratory of Parasitology. 148.

https://digitalcommons.unl.edu/parasitologyfacpubs/148

This Article is brought to you for free and open access by the Parasitology, Harold W. Manter Laboratory of at DigitalCommons@University of Nebraska - Lincoln. It has been accepted for inclusion in Faculty Publications from the Harold W. Manter Laboratory of Parasitology by an authorized administrator of DigitalCommons@University of Nebraska - Lincoln. 


\title{
COCCIDIAN PARASITES (APICOMPLEXA: EIMERIIDAE) FROM INSECTIVORES. VIII. FOUR NEW SPECIES FROM THE STAR-NOSED MOLE, CONDYLURA CRISTATA
}

\author{
Donald W. Duszynski \\ Department of Biology, The University of New Mexico, Albuquerque, New Mexico 87131
}

\begin{abstract}
Twenty-four star-nosed moles, Condylura cristata, collected from the northeastern United States (Maine, Massachusetts, Ohio, Vermont) were examined for coccidian oocysts. All of the moles were infected with from 1 to 4 species of coccidia representing 2 eimerian and 3 isosporan spp., but oocysts of only 4 of these species were present in sufficient numbers for detailed study; these are described as new. Sporulated oocysts of Eimeria condylurae n. sp. were subspheroid, $17.7 \times 15.7(17-23 \times 14-21) \mu \mathrm{m}$, with sporocysts ellipsoid, 11.7 $\times 5.6(11-14 \times 5-6) \mu \mathrm{m} ;$ E. condylurae was found in 3 of $24(12.5 \%)$ moles. Sporulated oocysts of Isospora condylurae n. sp. were ellipsoid, $19.4 \times 9.3(17-21 \times 8-11) \mu \mathrm{m}$, with sporocysts ovoid, $11.7 \times 5.8(11-13 \times$ 5-7) $\mu \mathrm{m}$; I. condylurae was found in 12 of 24 (50\%) moles. Sporulated oocysts of Isospora cristatae n. sp. were ellipsoid, $15.7 \times 10.1(13-18 \times 9-13) \mu \mathrm{m}$, with sporocysts ovoid, $11.0 \times 5.7(10-12 \times 5-7) \mu \mathrm{m} ;$ I. cristatae was found in 19 of 24 (79\%) moles. Sporulated oocysts of Isospora lamoillensis n. sp. were ellipsoid, tapering at both ends, $21.6 \times 13.0(19-23 \times 11-14) \mu \mathrm{m}$, with sporocysts spindle-shaped, $14.9 \times 7.7(14-16 \times 7-8) \mu \mathrm{m}$; I. lamoillensis was found in 2 of $24(8 \%)$ moles. Although the second eimerian seen was in 7 of the $24(29 \%)$ moles from Massachusetts, Ohio, and Vermont, there were not enough sporulated oocysts to study in detail to warrant a new species description. Including the 4 new species described here, there are now 48 valid eimerian species and 23 valid isosporan species described from insectivore hosts world-wide.
\end{abstract}

Of all extant mole species, none is more curious and bizarre than Condylura cristata (Linnaeus, 1758), the star-nosed mole, that gets its name from a ring of 22 fleshy appendages on the end of its nose (Yates, 1983). This species occurs throughout much of the northeastern United States and eastern Canada, and, unlike all other moles, it is semiaquatic. During our work on the coccidia of other North American moles (Ford and Duszynski, 1988, 1989), I had the opportunity to examine 24 star-nosed moles, all of which were infected with coccidians and were discharging large numbers of oocysts. Study of these oocysts led to the identity of 4 species, an eimerian and 3 isosporans, that are described here as new.

\section{MATERIALS AND METHODS}

Moles were live-trapped and fecal samples were collected from them and stored in $2.5 \%(\mathrm{w} / \mathrm{v})$ aqueous potassium dichromate $\left(\mathrm{K}_{2} \mathrm{Cr}_{2} \mathrm{O}_{7}\right)$. All methods for processing and storing fecal samples upon return to the laboratory, and for concentrating, measuring, and photographing oocysts have been described before (Duszynski et al., 1982; Stout and Duszynski, 1983). Measurements are in $\mu \mathrm{m}$ with size ranges in parentheses following the means. All oocysts were measured and photographed when they were between 49 and 68 days

Received 21 November 1988; revised 24 March 1989; accepted 29 March 1989. old (Isospora spp.) or when they were 627 days old (Eimeria spp.).

\section{RESULTS}

All 24 moles were collected from 4 localities: Ashtabula Co., Ohio (6), Franklin Co., Massachusetts (4), Lamoille Co., Vermont (12), and Pendoscot Co., Maine (2). Each host had numerous oocysts in its feces; 15 of 24 hosts (62.5\%) had multiple infections with from 2 to 4 coccidian species. More than $95 \%$ of all oocysts seen were isosporans and these represented 3 distinct species described below. Small numbers of eimerian oocysts were also seen; these could be distinguished as 2 species, but sporulated oocysts were present in sufficient numbers to allow careful study and description of only 1 of these.

\section{Eimeria condylurae n. sp.}

(Figs. 1-3, 13)

\section{Description}

Oocyst subspheroid (Figs. 1-3) with thick wall $(\sim 1.5)$ composed of 2 layers: outer layer smooth, yellow, $\sim 2 / 3$ of total thickness; inner layer pale yellow, smooth; micropyle and polar body absent; oocyst residuum irregularly shaped, highly refractile (transmitted light) body (Fig. 3), $\sim 2 \times 3$; sporulated oocysts $(n=33) 17.7 \times$ $15.7(17-23 \times 14-21)$ with $\mathrm{L} / \mathrm{W}$ ratio 1.1 (1.05-1.25); sporocysts $(n=20)$ ellipsoid, pointed at both ends, $11.7 \times 5.6(11-14 \times 5-6)$ with $\mathrm{L} / \mathrm{W}$ ratio 2.1 (1.92.6); Stieda and substieda bodies present (Figs. 1, 2), but parastieda body is absent; sporocyst residuum of 

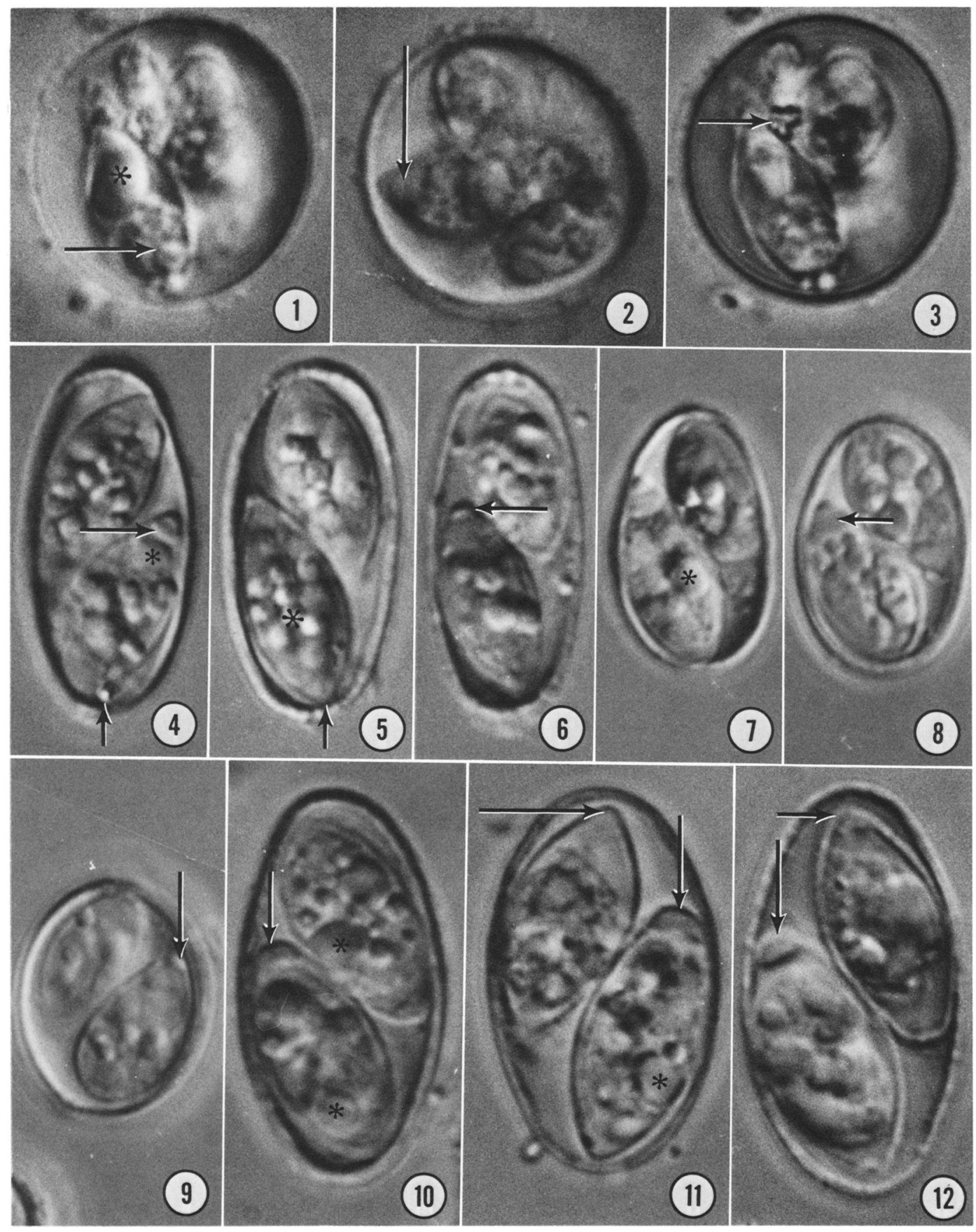

Figures 1-12. Photomicrographs of sporulated oocysts of coccidia collected from the feces of Condylura cristata. $\times 1,850.1-3$. Eimeria condylurae n. sp. 1. Note large posterior refractile body of sporozoite $\left({ }^{*}\right)$ and granular sporocyst residuum (arrow). 2. Note substieda body (arrow). 3. Note refractile oocyst residuum (arrow). 4-6. Isospora condylurae $\mathrm{n}$. sp. 4. Note small polar body (vertical arrow), refractile body of sporozoite $\left({ }^{*}\right)$, and substieda body (horizontal arrow). 5. Note sporocyst residuum $(*)$ and pointed end of sporocyst opposite Stieda body (arrow). 6. Note Stieda body (arrow). 7-9. Isospora cristatae $\mathrm{n}$. sp. 7. Note asymmetrical shape of oocyst and sporozoite refractile body $\left({ }^{*}\right)$. 8. Note substieda body (arrow). 9. Note Stieda body (arrow). 10-12. Isospora lamoillensis $\mathrm{n}$. sp. Note large Stieda body (vertical arrows), refractile body of sporozoite (*), and pointed end of sporocyst opposite Stieda body (horizontal arrows). 

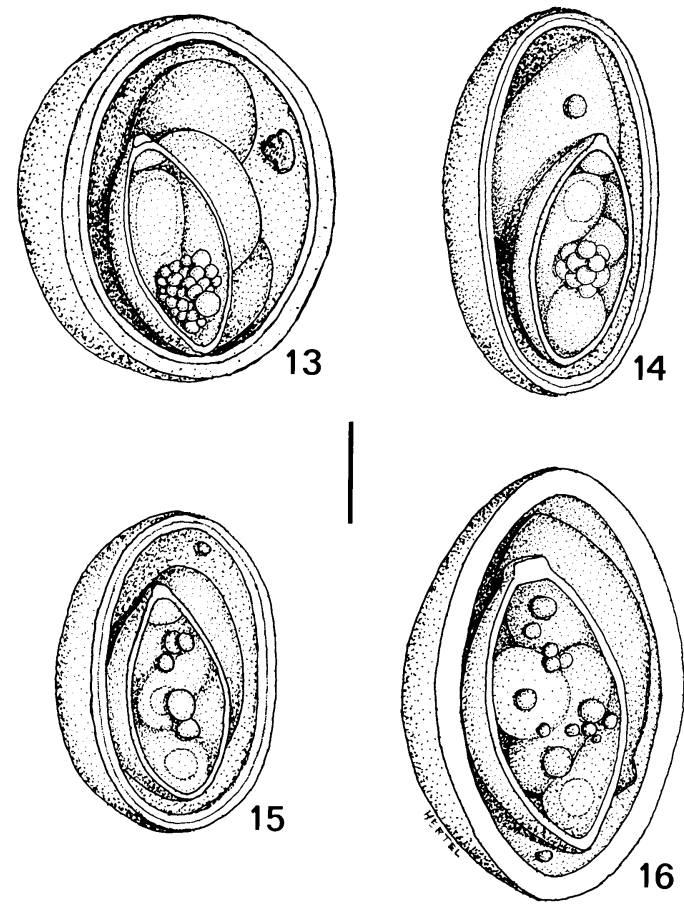

FIGURES 13-16. Line drawings of sporulated oocysts of coccidia collected from feces of Condylura cristata. $\mathrm{Bar}=5 \mu \mathrm{m}$. 13. Eimeria condylurae. 14. Isospora condylurae. 15. Isospora cristatae. 16. Isospora lamoillensis.

large granules that may be a compact mass or diffuse and occupies $\sim 1 / 2$ of sporocyst. Sporozoites with a large posterior refractile body.

\section{Taxonomic summary}

Type host: Condylura cristata (Linnaeus, 1758).

Type locality: Lamoille County, Vermont, $10.3 \mathrm{~km}$ N Stowe off Highway 100.

Prevalence: Found in 3 of 24 (12.5\%) C. cristata including 2 of $12(17 \%)$ from Vermont and 1 of $6(17 \%)$ from Ohio. feces.

Site of infection: Unknown, oocysts collected from

Material deposited: Syntypes (=phototypes, see Bandoni and Duszynski, 1988) of sporulated oocysts in the U.S. National Museum (USNM), Beltsville, Maryland, Parasite Collection No. 80625. Host skin, skull, skeleton, and tissues (heart, kidney, liver) in the Division of Mammals, Museum of Southwestern Biology (MSB), The University of New Mexico (UNM), NK 3024 (male), R. M. Sullivan \#479, 13 June 1980, MSB \#43334.

Etymology: The nomen triviale is derived from the generic name of the host.

\section{Remarks}

Sporulated oocysts of this eimerian resemble in size and shape those of Eimeria madagascarensis Uilenberg, 1967, from the Madagascar "hedgehog," Setifer setosus. They differ, however, by being slightly larger
$(18 \times 16$ vs. $16 \times 15)$ and by having sporocysts that have a substieda body and that are pointed at the end opposite the Stieda body, both features that are absent in $E$. madagascarensis.

\section{Isospora condylurae n. sp.}

(Figs. 4-6, 14)

\section{Description}

Oocyst ellipsoid (Figs. 4-6), sometimes slightly asymmetrical; wall $\sim 1.0$, with 2 layers of equal thickness, but difficult to distinguish in intact oocyst: outer layer smooth; micropyle and oocyst residuum absent, but small refractile polar body is present; sporulated oocysts $(\mathrm{n}=50) 19.4 \times 9.3(17-21 \times 8-11)$ with L/W ratio $2.1(1.7-2.3)$; sporocysts $(n=50)$ elongateovoid, $11.7 \times 5.8(11-13 \times 5-7)$ with $\mathrm{L} / \mathrm{W}$ ratio 2.0 (1.8-2.4); Stieda and substieda bodies present (Figs. 4, 6 ), with substieda body $2 \times$ wider than Stieda body, but parastieda body is absent; sporocyst residuum of 10-12 homogeneous globules, dispersed (Figs. 4, 6) or in a compact mass (Fig. 5); sporozoites with 1 obvious refractile body in posterior half of body.

\section{Taxonomic summary}

Type host: Condylura cristata (Linnaeus, 1758).

Type locality: Lamoille County, Vermont, $9.7 \mathrm{~km}$ N Stowe, ungrazed pasture by Highway 100.

Prevalence: Found in 12 of $24(50 \%)$ C. cristata including 7 of $12(58 \%)$ from Vermont, 3 of $6(50 \%)$ from Ohio, and 2 of $4(50 \%)$ from Massachusetts.

Site of infection: Unknown, oocysts collected from feces.

Material deposited: Syntypes (=phototypes) of sporulated oocysts in the USNM Parasite Collection No. 80626. Host skin, skull, skeleton, chromosomes, tissue culture cells, tissues (heart, kidney, liver), and serum in the MSB, Division of Mammals, NK 3038 (male), K. McBee \#96, 14 June 1980, MSB \#43346.

Etymology: The nomen triviale is derived from the generic name of the host.

\section{Remarks}

Oocysts and sporocysts of this isosporan have the largest $\mathrm{L} / \mathrm{W}$ ratios of any isosporans described from insectivores; because of this and the presence of other features (e.g., substieda body) these sporulated oocysts do not resemble those from any species previously described from insectivores.

\section{Isospora cristatae n. sp.} (Figs. 7-9, 15)

\section{Description}

Oocyst ellipsoid (Figs. 8, 9), sometimes asymmetrical (Fig. 7); oocyst wall $\sim 1.0$ composed of 2 layers of equal thickness, outer layer smooth; micropyle and oocyst residuum absent, but small polar body is present; sporulated oocysts $(n=50) 15.7 \times 10.1(13-18$ $\times 9-13)$ with $\mathrm{L} / \mathrm{W}$ ratio $1.55(1.35-1.8)$; sporocysts $(\mathrm{n}$ $=50)$ ovoid, $11.0 \times 5.7(10-12 \times 5-7)$ with $\mathrm{L} / \mathrm{W}$ ratio 1.9 (1.6-2.1); Stieda and substieda bodies present (Figs. 7,8 ), with substieda body $>2 \times$ wider than Stieda body, but parastieda body is absent; sporocyst residuum with 2-8 dispersed globules; sporozoites with 1 refractile body in posterior half of body. 


\section{Taxonomic summary}

Type host: Condylura cristata (Linnaeus, 1758).

Type locality: Ashtabula County, Ohio, 2302 Morningside Dr., Ashtabula.

Prevalence: Found in 19 of 24 (79\%) C. cristata including 9 of $12(75 \%)$ from Vermont, 5 of $6(83 \%)$ from Ohio, 3 of 4 (75\%) from Massachusetts, and 2 of 2 from Maine. feces.

Site of infection: Unknown, oocysts collected from

Material deposited: Syntypes (=phototypes) of sporulated oocysts in the USNM Parasite Collection No. 80627. Host skin, skull, skeleton, and tissue culture cells in the MSB, Division of Mammals, NK 3112 (male), R. M. Sullivan \#512, 28 June 1980, MSB \#43403.

Etymology: The nomen triviale is derived from the specific part of the scientific name of the host.

\section{Remarks}

Sporulated oocysts of this isosporan are similar in size and shape to those of Isospora dymecodi Duszynski and Moore, 1986, from Dymecodon pilorostris True, 1886, a Japanese shrew mole and to those of Isospora sporopointaea Duszynski and Wattam, 1988, from Talpa europaea, the European mole. They differ from I. dymecodi oocysts by having a larger $\mathrm{L} / \mathrm{W}$ ratio $(1.55$ vs. 1.25) and by having sporocysts with both Stieda and substieda bodies that those of $I$. dymecodi lack. They differ from oocysts of $I$. sporopointaea in many ways. They have a smooth outer oocyst wall (vs. mammillated) and a polar body that is absent in I. sporopointaea. In addition, their sporocysts are rounded at end opposite Stieda body (vs. pointed) and have substieda bodies that are $2 \times$ wider than the Stieda body (vs. equal in width).

\section{Isospora lamoillensis n. sp.}

(Figs. 10-12, 16)

\section{Description}

Oocyst ellipsoid, tapers slightly toward both ends (Figs. 10, 12), with wall $\sim 1.5$ composed of 1 obvious layer; micropyle and oocyst residuum absent, but polar body is present; sporulated oocysts $(n=25) 21.6 \times$ $13.0(19-23 \times 11-14)$ with $\mathrm{L} / \mathrm{W}$ ratio $1.7(1.4-1.8)$; sporocysts $(n=25)$ spindle-shaped, tapering toward a point at end opposite Stieda body (Figs. 11, 12), 14.9 $\times 7.7(14-16 \times 7-8)$ with $\mathrm{L} / \mathrm{W}$ ratio $1.95(1.8 \times 2.2)$; wide Stieda body present (Figs. 10-12), but sub- and parastieda bodies absent; sporocyst residuum of many dispersed granules of various sizes; sporozoites with 1 obvious refractile body in middle of body (Fig. 10).

\section{Taxonomic summary}

Type host: Condylura cristata (Linneaus, 1758).

Type locality: Lamoille County, Vermont, $6.4 \mathrm{~km}$ E, $3.2 \mathrm{~km} \mathrm{~S}$ Morrisville.

Prevalence: Found in 2 of 24 (8\%) C. cristata including 1 of $6(17 \%)$ from Ohio and 1 of $12(8 \%)$ from Vermont. fite

Material deposited: Syntypes (=phototypes) of sporulated oocysts in the USNM Parasite Collection No.
80628. Host skin, skull, skeleton, chromosomes, tissue culture cells, and tissues (heart, kidney, liver) in the MSB, Division of Mammals, NK 3055 (female), R. M. Sullivan \#488, 17 June 1980, MSB \#43323.

Etymology: The nomen triviale combines the name of the county in Vermont from which the first infected moles were caught and -ensis (L., belonging to).

\section{Remarks}

Sporulated oocysts of this isosporan most closely resemble those of $I$. sporopointaea and those of Isospora talpae Agostinucci, 1955, both from the European mole, T. europaea. They differ from those of I. sporopointaea by not having a mammillated outer wall, by having a polar body, by having larger oocysts with a larger $\mathrm{L} / \mathrm{W}$ ratio (1.7 vs. 1.5$)$, and by lacking a substieda body that the sporocysts of $I$. sporopointaea possess. They differ from those of $I$. talpae by lacking a micropyle, by having a polar body, by the shape of the Stieda body (flat vs. nipplelike), and by having sporocysts that are pointed at the end opposite the Stieda body, whereas those of I. talpae are rounded.

\section{DISCUSSION}

Condylura cristata is the fourth of the 7 known North American talpids (moles, shrew moles) that my students and I have examined for coccidia (Duszynski, 1985; Ford and Duszynski, 1988, 1989). Three of these species, C. cristata; Parascalops breweri (Bachman), the hairy-tailed mole; and Scalopus aquaticus (Linnaeus), the Eastern mole, occur in the eastern two-thirds of the United States and have ranges that overlap (Hall, 1981). The other 4 species, Neurotrichus gibbsii Baird, a shrew mole; Scapanus townsendii (Bachman), Townsend's mole; Scapanus orarius True, the coast mole; and Scapanus latimanus (Bachman), the broad-footed mole, are all confined mainly to the western coastal states (Hall, 1981).

Because $C$. cristata is morphologically unique, it has been placed historically in a subfamily (Condylurinae) separate from the other 6 North American talpids (Scalopinae) (Hall, 1981). In addition, cladistic and other analyses of genic data (Moore, 1986) indicated that Condylura diverged very early from the main talpid lineage (26 million years before present), long before talpids appeared in North America. Thus, it is likely that the Condylurinae first appeared in Eurasia and invaded the New World when a land bridge connected Asia and North America either during the early or late Miocene (Moore, 1986). Although the ancestors of $C$. cristata became isolated in North America as long ago as 8 million years (see Hutchison, 1984) and their current ranges overlap those of 2 other North American 
mole species, it might still be predicted that their coccidia should be structurally more similar to the coccidia from Eurasian moles, given the historical and genic data presented by Moore (1986). In fact, $C$. cristata is the only insectivore we have examined to date that was infected almost exclusively by isosporans. The oocysts of these Isospora spp. are indeed more similar morphologically to oocysts of isosporans from Eurasian moles than they are to isosporans found in North American talpids.

Finally, moles have very high infection rates with coccidians and most individual hosts harbor multiple infections (Duszynski and Wattam, 1988a, 1988b; Ford and Duszynski, 1988, 1989). The infection pattern in C. cristata is consistent with this observation. To date, we have examined 195 individual moles belonging to 8 species and 6 genera from England, Japan, and the United States; $183(94 \%)$ have been infected with coccidia and $153(84 \%)$ of those infected had oocysts from 2 to 8 coccidian species in their feces when examined.

\section{ACKNOWLEDGMENTS}

This study was supported partly by $\mathrm{NIH}-$ DHHS grant 5 S06, RR-08139-07 to the University of New Mexico (D. W. Duszynski and T. L. Yates) and partly by NSF grant DEB- 8004685 to T. L. Yates. Sincere thanks to Drs. D. W. Moore, R. M. Sullivan, and T. L. Yates and to $\mathrm{K}$. McBee for their help collecting moles and in other aspects of this project. Special thanks are due Lynn A. Hertel for the line drawings.

\section{LITERATURE CITED}

BANDONI, S. M., AND D. W. DuszYNSKI. 1988. A plea for improved presentation of type material for coccidia. Journal of Parasitology 74: 519-523.
DUSZYNSKI, D. W. 1985. Coccidian parasites (Apicomplexa: Eimeriidae) from insectivores: New species from shrew moles (Talpidae) in the United States. Journal of Protozoology 32: 577-580.

, G. EAstham, AND T. L. YATES. 1982. Eimeria from jumping mice (Zapus spp.): A new species and genetic and geographic features of $Z$. hudsonius luteus. Journal of Parasitology 68: 1146-1 148.

- , AND A. R. WATTAM. 1988a. Coccidian parasites (Apicomplexa: Eimeriidae) from insectivores. V. Ten forms from the moles of Japan ( $E u$ roscaptor, Mogera spp.). Journal of Protozoology 35: 55-57.

$\longrightarrow$ AND $\longrightarrow$ 1988b. Coccidian parasites (Apicomplexa: Eimeriidae) from insectivores. IV. Four new species in Talpa europaea from England. Journal of Protozoology 35: 58-62.

FORD, P. L., AND D. W. DUSZYNSKI. 1988. Coccidian parasites (Apicomplexa: Eimeriidae) from insectivores. VI. Six new species from the eastern mole, Scalopus aquaticus. Journal of Protozoology 35: 223-226.

— complexa: Eimeriidae) from insectivores. VII. Six new species from the Hairy-tailed mole, Parascalops breweri. Journal of Parasitology 75: 508513.

Hall, E. R. 1981. The mammals of North America, 2nd ed., Vol. I. John Wiley and Sons, New York, p. 66-76.

Hutchison, J. H. 1984. Cf. Condylura (Mammalia: Talpidae) from the late Tertiary of Oregon. Journal of Vertebrate Paleontology 4: 600-601.

MOORE, D. W. 1986. Systematic and biogeographic relationships among the Talpinae (Insectivora: Talpidae). Ph.D. Dissertation. University of New Mexico, Albuquerque, $105 \mathrm{p}$.

Stout, C. A., AND D. W. DuszYNSKI. 1983. Coccidia from kangaroo rats (Dipodomys spp.) in the western United States, Baja California, and northern Mexico with descriptions of Eimeria merriami sp. n. and Isospora sp. Journal of Parasitology 69: 209-214.

YATES, T. L. 1983. The mole that keeps its nose clean. Natural History 92: 54-61. 